\title{
臨
}

床

\section{$\alpha$-Ketoglutarate を基質とした肝 $\delta$-aminolevurinic}

\author{
acid 合成活性の異常高值を示した \\ variegate porphyria $の 1$ 例
}

\begin{tabular}{|c|c|c|c|c|c|c|c|}
\hline & & & 京大学哣 & 部第三内 & & & \\
\hline 児玉 & 龍彦。 & 高木 & 正雄 & 小林 & 高義 & 森 & 真由美 \\
\hline 千葉 & 省三 & 大久佔 & 昭行 & 寺尾 & 寿夫 & 小坂 & 樹徳 \\
\hline & 国立 & 徫生院 & 浦田 & 郡平 & 近藤 & 雅夫 & \\
\hline & 横 & 信病院 & 高橋 & 次雄 & & & \\
\hline
\end{tabular}

\section{A CASE OF VARIEGATE PORPHYRIA AND HER HEPATIC $\delta$-AMINOLEVURINIC ACID SYNTHETIC ACTIVITY}

Tatsuhiko Kodama, MD, Masao TAKAGI, MD, Takayoshi KobayashI, MD, Mayumi Mori, MD, Shozo Chiba, MD, Akiyuki Oнкuвo, MD, Toshio Terao, MD and Kinori Kosaka, MD

The Third Department of Internal Medicine, Faculty of Medicine, University of Tokyo Gumpei Urata, PhD and Masao Kondo, PhD

The National Institute of Pubric Health, Tokyo

Tsuguo T AKaHASHI, MD

Yokohama Teishin Hospital, Yokohama

\begin{abstract}
概要 Variegate porphria (VP) は，肝におけるへム合成系の醉素異常を原因とし，神経，筋症状と

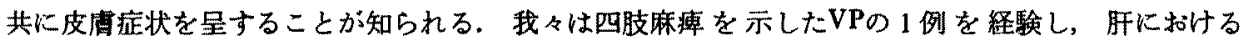
$\delta$-aminolevurinic acid (ALA) 合成活性の特異な上昇を証明した，症例は33才，女性で，第一子出産 後, 腹痛，呕吐で発症し，フェノハーール投与後四肢麻疸を㧍こし，同時に肝機能，電解質の異常を示 した. 皮唐の光線過敏，皮疹，および急性期に尿中ALA，porphobirinogenが上昇し，便中のcoproporphyrin，protoporphyrinが寛解期にも高值を示したことからVPと診断された. 肝性porphyriaには 4 型が 知られるが，各病型と肝へム合成采の異常については不明の点が多い，そこで，本例の肝生検組織 に拈けるALA合成活性をsuccinyl CoAを基質とした $\mathrm{S}$ 活性と $\alpha$-ketoglutarateを基質とした $\mathrm{K}$ 活性につ いて測定した. S 活性はacute intermittent porphyria (AIP) 例之同程度に上昇し，K活性はAIPp porphyria cutanea tarda例の $2 \sim 5$ 倍にあたる上界を認めた．生検所見では肝には電顕所見で層状と なつた膜梯の特異な構造を誌め,脂肪滴の沈着が見られた。これは従来の報告とあわせ肝性porphyria に特異な所見と思われる. 肝におけるALA合成K活性の特異な上昇は本例の多量のporphyrin体産生 や，重度の神経筋症状に大きな影䈏を与えたと思われた．K活性はS 活性より生理的なALA合成をよ り上く反映すると思われ，これを中心に肝性porphyriaにおける䤃素異常について考察した。
\end{abstract}

〔昭和52年11月12日 第279回関東地方会推薦] 


\section{緒 言}

肝性porphyriaは肝に批けるへム合成系酵素異常 のため, porphyrin体が過㮃産生され，神経，筋症 状や, 肝機能異常, 電解質異常, 皮疹など多彩な 全身症状を示す疾患として知られる。臨床症状 および血液，尿，便中に増加する porphyrin体のパ ターンにより acute intermittent porphyria (AIP), variegate porphyria (VP), porphyria cutanea tarda (PCT) 等の病型が知られている゙'。一産生の 律速酵素であるALA合成醭の活性がAIP, VP では上昇していることが示されているが，従来 のALA合性活性の測定方法は多量の肝組織を必要 としたため，生前に行ならことは大さな困難を伴 つていた。最近，放射性同位元素を用いて，10mg 程度の微量の肝組織より mitochondria分画のALA 合成活性を測定する方法が開発されている4).

今回我々は典型的なVPの 1 例を経験し, 微量測 定法を用い検索した結果， $\alpha$-ketoglutarate $(\alpha \mathrm{KG})$ を基質とした時に，肝でのALA合成活性が特異な 上年を示すと共に，他の肝性porphyria との比較， 検討を行ないまた病理組織学的にも興味ある所見 を認めたので報告する。

患者：33才, 主婦.

主訴：四肢麻痺, 全身倦怠.

家族歴：母(68才)は, 19才頃より，腹痛， 呕吐の発作が何回かあり，その際尿が赤変したと い5．顔一面に深いしわがあり，皮膚の一部に水 泡が見られた。

既往歴：18才虫垂切除術, 妊娠 2 回, 万ち 1 回自然流産.

現病歴：1977年 1月19日（第一子出産約 1 力 月後) 早朝より上腹部に局在性のはつきりしない 鈍痛を感し，悪心，呕吐が出現し，尿が赤くなつ た．近医にて感冒といわれ，抗生物質の投与をう けたが，軽快せず，24日横浜逓信病院に入院した。

横浜派信病院での経過：入院後, 悪心, 呕吐 はおさまつたが，興奮状態続き，不眠を訴えたた め，10\%フェノバール筋注をうけた。初め両下肢
を針でチクヂさすよらな痛みがあり，それが全 身に広がつた，尿が再び赤くなり，尿中porphyrin 体が定性で陽性となつたためフェノバール注射は 31 日中止した。 2 月 3 日，食事中両下肢に脱力 が出現し，同時に嗄声む出現した．四肢麻痺は遠 位に強く，弛緩性であつた，同時に高血圧 (140〜 $170 / 100 \sim 120)$ および洞性頻脈（100 140/分）と なつた。

横浜逓信病院に入院当初は, 血算, 電解質に特 に異常なく，肝機能 す 総コレステロール $308 \mathrm{mg} / \mathrm{dl}$ と高值の他は正常であつたが，四肢麻疸発症後 2 月 7 日血清 $\mathrm{Na} 129 \mathrm{mEq} / l, \mathrm{Cl} 86 \mathrm{mEq} / l$ まで低下. 尿中Na，Clの排泄はそれぞれ193mEq/日，172mEq/ 日と増加し，血清ADHも高值を示した．総コレ ステロールも $437 \mathrm{mg} / \mathrm{dl}$ 上昇した。 2 月10日には GOT，GPTは，それぞれ205KU 185KUであつた （図 1 ）. 5\% glucoseを主とした輸夜が行なわれ， 2 月中旬より, 嗄声, 四肢麻疸は徐々に改善し始 め, 肝機能, 電解質も正常化してきた。3月には いり, 肘関節, 䐂関節の屈伸も可能となつた。 porphyria精査のため東大第三内科へ 5 月 24 日転院 した.

東大第三内科入院時現症：身長 $150 \mathrm{~cm}$, 体重 $35 \mathrm{~kg}$, 食欲不振, 便秘で神経質な小柄の女性. 色 はあさ黒く下肢に剛毛がみられた。手背に浮腫と

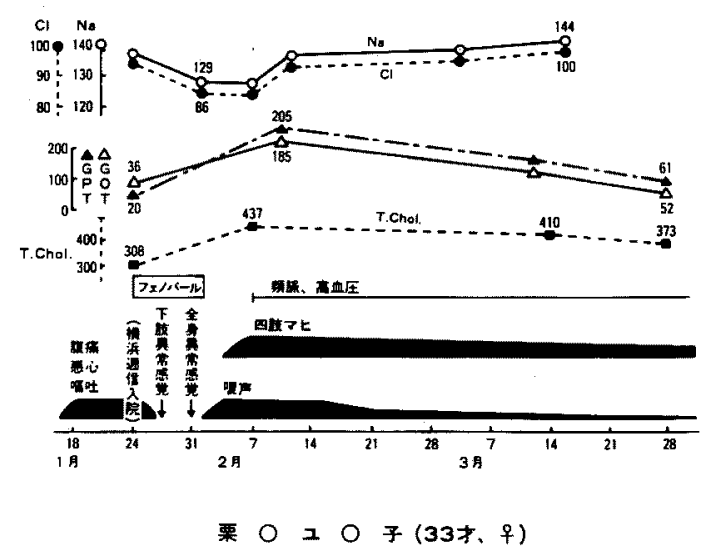

図 1. 発症後東大第三内科入院前（横浜派信病院） の臨床程過 
米粒大隆起性口疹を認めた，脈拍 $100 /$ 分，血圧 168/108, 頭額部正常. 胸部聴打診正常. 腹部で は表面平滑，辺縁やや鈍の肝を右季肋部に 2 横指 ふれた．脾，腎はふれなかつた。

神経学的には，やや神経質だが，意識清明，見 当識等は正常. 瞳孔は正円, 左右同大. 眼球運 動, 嚥下等に異常なく, 脳神経は正常. 筋力は上 肢遠位 1 度, 近位 $1 \sim 2$ 度, 下肢遠位 $2 \sim 3$ 度, 近位 $2 \sim 4$ 度で, 遠位に強い低下を認めた. 握力 は $0 \mathrm{~kg}$, 歩行, 起立不能であつた. 反射 は二頭 筋, 三頭筋反射はやや低下，腹壁反射，アキレス 腱反射, 㮏蓋腱反射は消失して打り，四肢は弛緩 性麻痺を示した。異常運動, 異常反射, 運動失調 はなく, 知覚系は, 位置覚, 温痛覚, 振動覚いず れも正常だつた。

東大第三内科入院時一般検査成樍 : 尿検査で は蛋白 $(+)$, porphyrin体 (十) であつた (porphylin体の詳細は後述する). 血算は正常, 生化学 的にも総コレステロールの他には異常は認められ なかつた（表 1 )。心電図では洞性頻脈でST低
表 1 . 入院時检査所見

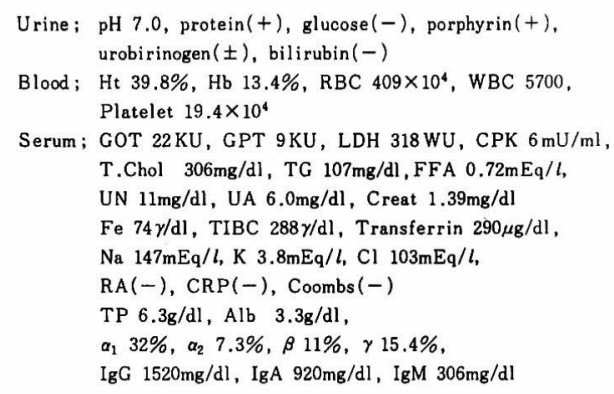

下, T逆転がI，aVL， $V_{4 \sim 6}$ で認められた. 筋電図 では上下肢共, low voltage, short duration, polyphasie patternを認め, 筋原性, 神経原性が混在 した所見を示した。100gGTTは糖尿病パターンで その際，成長ホルモンが奇異的に上昇した。

生検組織所見：1）肝；腹胿鏡では肝はや や暗い灰褐色で腫大していた. 生検像ではグリン ン鞘周辺に軽度の細胞浸潤を認めた．細胞質内に は多数の脂肪滴が沈着し，一部にはリポフスチン 様物質がみられた（写真 1 ). mitochondria内には

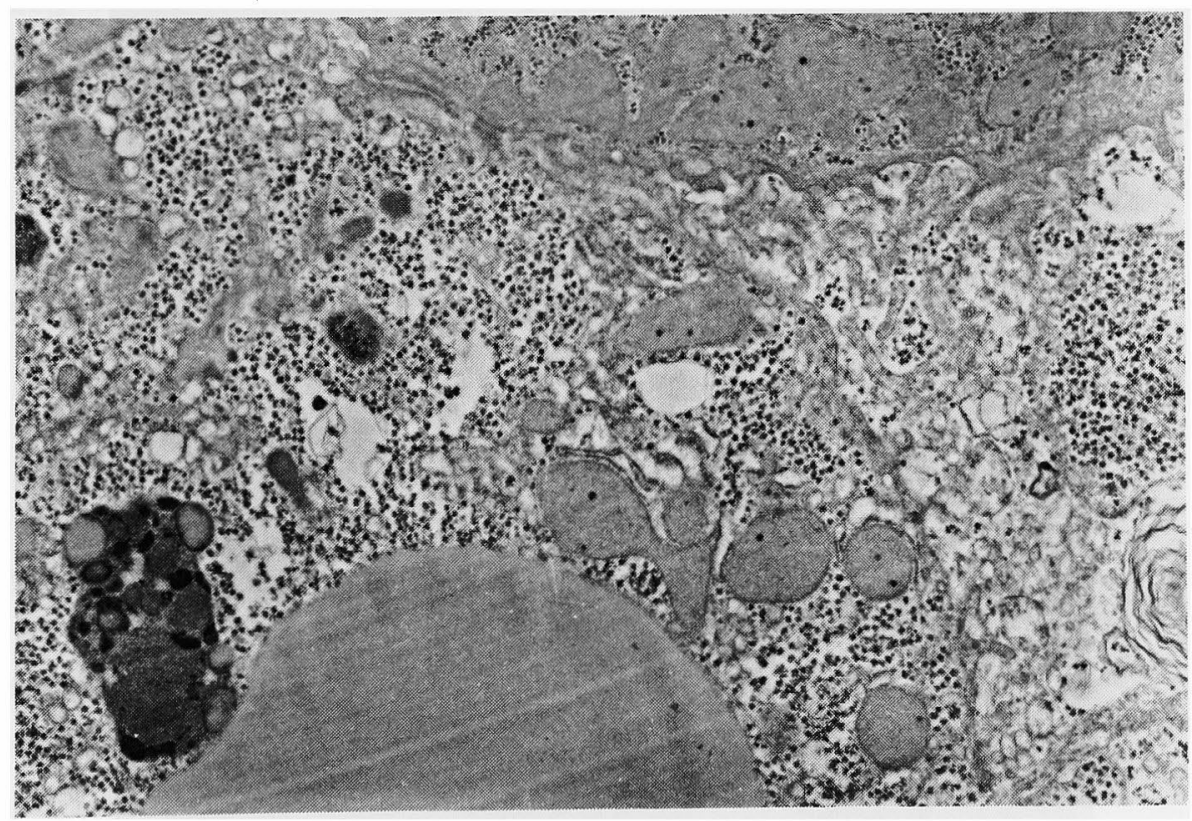

写真 1. 肝電顕像. 右端にmyeline figure梯構造がみられ, mitochondria内に濃い顆粒があ る. 脂肪滴沈着もみられる。 


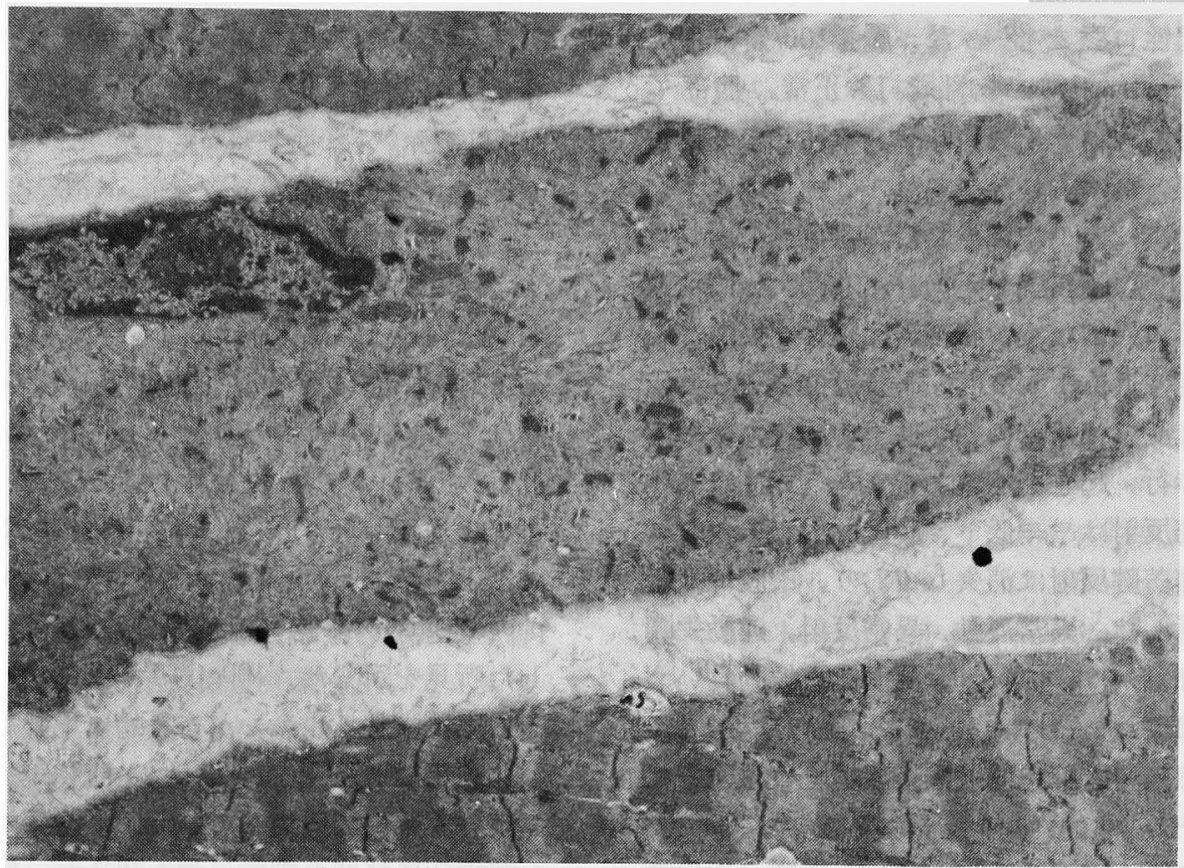

写真 2 . 筋肉電顕像

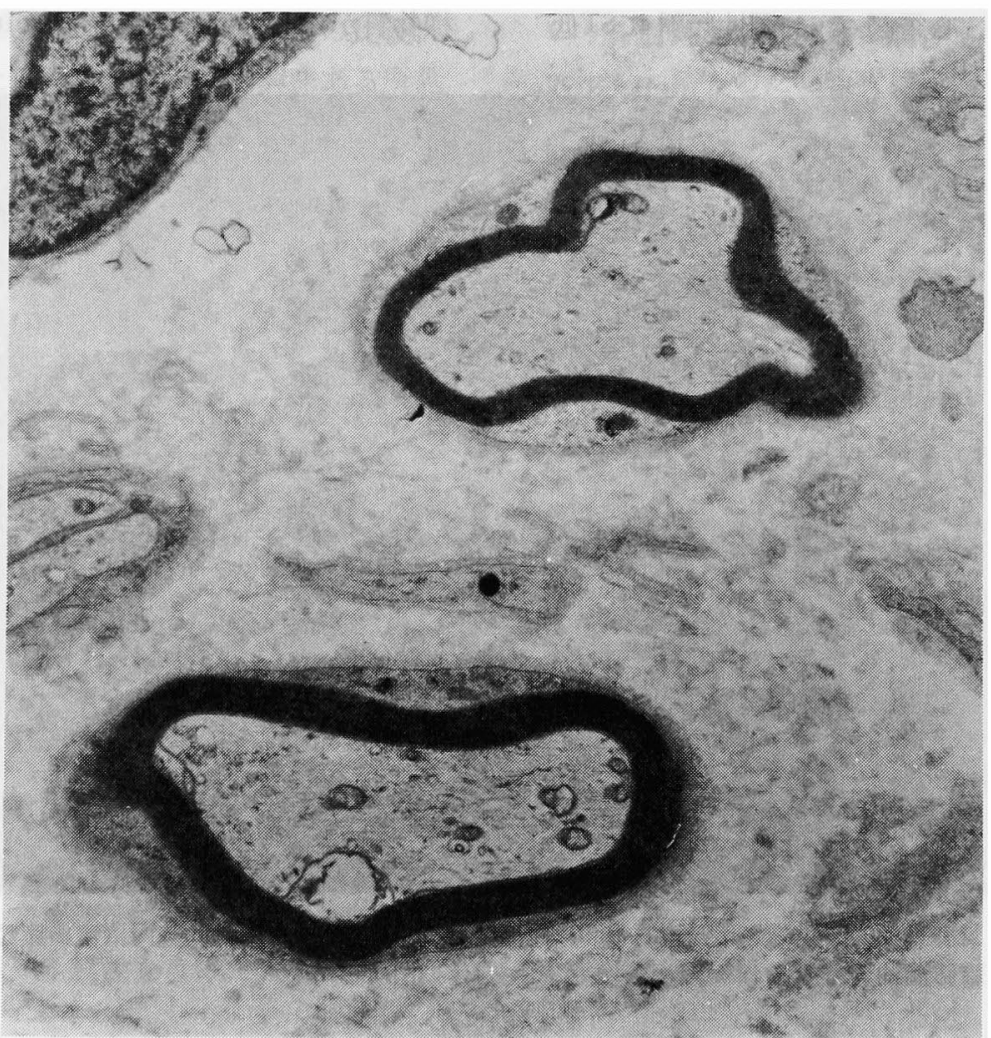

写真 3 . 末梢神経電顕像 


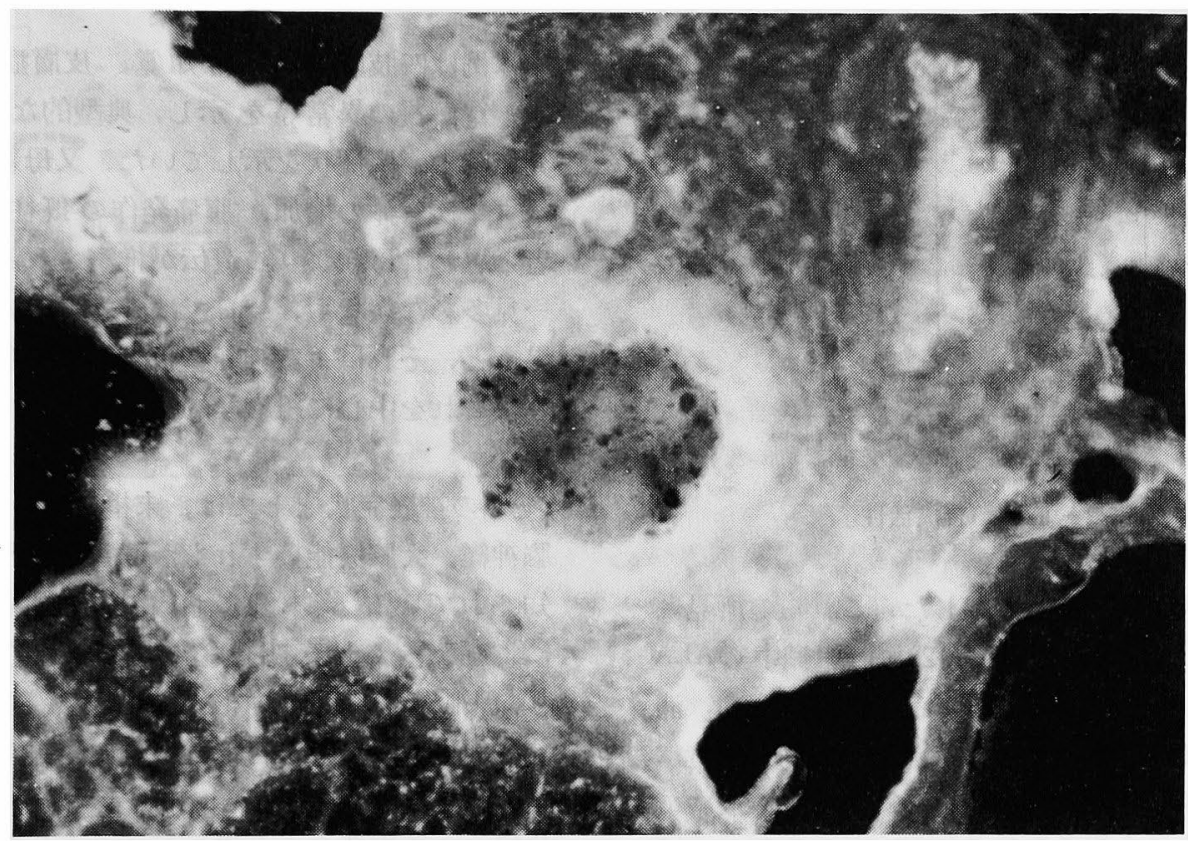

写真 4. 末梢血管へのIgG沈着

electron denseの小体があり，一部の 肝細胞には myelin figure様の竲状構造を認められた，2）皮 膚; 手背の皮膚生検組織ではhyperkeratosis著明 で, 表皮はrate ridge消失しatrophicであり，真皮 上層から深層までfibroblastの増殖著明で血管新生 む多く皮疹をくり返したと考えられる像を示し た. 3）筋肉・末梢神経; 大腿四頭筋の生検組 織では, angulated fiber, grouped atrophyがあり， 電顕的にも Z 帯のstreamingがみられた (写真 2 ). 筋組織中へも脂肪滴沈着は増加していた. 筋肉中 の末梢神経には髄鞘の菲薄化がみられ脱髄様のパ ターンと考えられた（写真 3 ). 筋組織中 の 血管 壁へはIgG沈着が蛍光抗体法により示された（写 真 4 ).

Porphyrin代謝の検討：1）血液, 尿, 便中 のporphyrin体濃度は急性期（2月16日）と症状 安定期（6月15日）において表 2 の通りであつ た. 急性期には, 尿中ではALA PBG, uroporphyrin, coproporphyrinが 増加していたが, 安定期に
表 2 . 尿, 血液, 便中のポルフィリン体濃度

Patient Patient's

$16 / 1$ I $15 / \mathrm{VI}$ mother

\begin{tabular}{llrrr}
\hline Urine & & & & \\
ALA & $(1-4 \mu \mathrm{g} / \mathrm{ml})$ & 20.6 & 10.4 & 5.78 \\
PBG & $($ trace $\mu \mathrm{g} / \mathrm{ml})$ & 24.2 & 5.98 & trace \\
Uroporphyrin & $(0.4-4.0 \mu \mathrm{g} / \mathrm{dl})$ & 110 & 29.2 & trace \\
Coproporphyrin & $(4.0-20.0 \mu \mathrm{g} / \mathrm{dl})$ & 285 & 119.5 & 8.0 \\
Protoporphyrin & $($ trace $\mu \mathrm{g} / \mathrm{dl})$ & 0 & 0 & 0
\end{tabular}

\begin{tabular}{|c|c|c|c|c|}
\hline \multicolumn{5}{|l|}{ Blood } \\
\hline Uroporphyrin & (trace $\mu \mathrm{g} / 10 \mathrm{ml}$ ) & trace & trace & trace \\
\hline Coproporphyrin & $(0-0.2 \mu \mathrm{g} / 10 \mathrm{ml})$ & 0.5 & 0.55 & 0.65 \\
\hline Protoporphyrin & $(1.5-3.0 \mu \mathrm{g} / 10 \mathrm{ml})$ & 2.74 & 2.50 & 5.34 \\
\hline \multicolumn{5}{|l|}{ Stool } \\
\hline Uroporphyrin & (trace $\mu \mathrm{g} / \mathrm{lgw} \cdot \mathrm{w})$ & trace & - & - \\
\hline Coproporphyrin & $(2-10 \mu g / l g w . w)$ & 297 & 129 & 143 \\
\hline Protoporphyrin & (3-15 $\mu g / 1 g w . w)$ & 187 & 127 & 39 \\
\hline
\end{tabular}

なると尿中のLAL，PBG等はやや低下の傾向をみ せるのに対し, 便中の) coproおよびprotoporphyrin は, 正常値の約10倍の高值を保つている. 血中で 


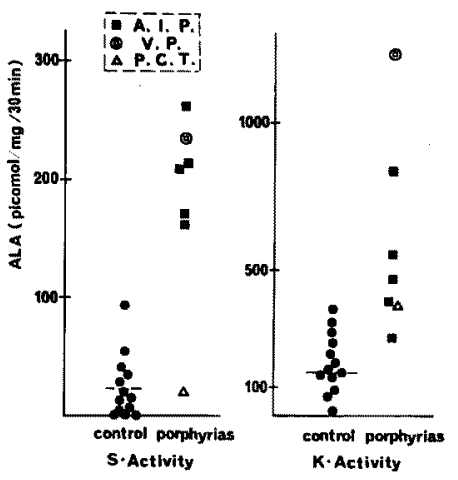

図 2, 肝ALA合成活性

のporphyrin体は正常值を示した。これらの所見は VPの特徵 と一致していた．2) 肝組織中のALA 合成活性；肝組織中のALA合成活性測定は，浦 田らの方法を用いて行なつだ). needle biopsyに より採取された肝組織10mgを $0.25 \mathrm{M}$ 蔗糖溶液中で ホモジナイズし，20000Gで30分遠心分離し，沈 渣をALA合成活性測定に用いた。沈椬を 2 つ分 け，一方はglycine 之 $1-4-{ }^{14} \mathrm{C}$-succinyl CoAを基質 とし合成される radioactiveなALAの量（S 活性） を測定し，む 5 一方はglycine $と 5-{ }^{14} \mathrm{C}-\alpha$-ketoglutarateを基質とするALA合成活性（K活性）を測定 した。

同時に、コントロールとして他の肝性porphyria であるAIP 5 例, PCT 1 例, porphyria以外の肝 疾患13例でのALA合成活性を測定值と比較した。

結果は図 2 のとおりで，本例においては S 活性 234.0 (以下単位はいずれもALA picomol/protein $\mathrm{mg} / 30 \mathrm{~min}$ ) K活性1229.1，一方コントロール群で は，AIP 5 例平均では， S 活性204.6（162.3〜 212.3）K活性503.3（272.8～830.1）PCT例では $\mathrm{S}$ 活性21.9, K活性386.1, 他肝疾患13例平均 $\mathrm{S}$ 活性23.1，K活性168.5であつた。

入院後経過：入院後, 神経学的異常は順調に 回復し，四肢麻疩も着実に改善をみ，歩行，自力 での食事摄取可能となり, 約 3 カ月の入院で退院 した。

\section{考 案}

本例は四肢麻㾝, 異常知覚, 皮唐症状, 肝機 能，電解質の異常等を示し，典型的なVPの急性 発作時の臨床症状を示していた。 又母親も便中ポ ルフィリン体の增加, 腹痛発作の 既往よりVP患 者と思われ母親よりの遺伝が推察される。これら 一見多彩な症状る，今日では肝でのへム合成系の 異常と，それによる神経障害として理解されて拉 ク，これを中心に組織学的検討を含めて考察した W.

VPの神経症状としては，末梢神経，自律神経， 脳神経，大脳機能いずれもが障害されうることが 知られている によると思われる四肢麻瘏, 異常知覚が認めら れ，不眠，興奮等の中枢神経症状がみられた．腹 痛, 便秘についても自律神経系の障害によると考 えられている ${ }^{5}$. 高血圧, 頻脈等も交感神経緊張 状態飞よる影響が大と思われる，内分泌，代謝上 の異常では，成長ホルモンの糖負荷時奇異的上昇 や，ADH分泌異常に上る低Na血症等，視床下部 障害致が推察されている。

神経障害の組織学的所見については, 脱葡を一 次的と考えるるの ${ }^{7}$ 軸索や細胞の变化を一次的之 考劣るもの ${ }^{8)}$ 血管の疼縮の結果，虚血性に神 経病変をおこしたと唱える説" があるが，本例の 末梢神経の電顕所見は，䯣鞘の菲薄化の所見を示 していた。また，筋肉内の血管周辺へのIgGの沈 着は, 免疫学的な機序による変化も示唆してい る・

肝でのへム合成系の異常と, 同時にこれらの神 経障害が接こることは明らかとされているが，そ の関連については不明な点が多い。ここでは特に 肝に拉けるへム合成の律速段階とされているALA 合成に焦点をあわせて検討したい。

肝に打けるALA合成は，図 3 の通り， $\alpha \mathrm{KG}$ か らTCA回路によつて succinyl CoAが作られ, こ れとglycineが 縮合してALAが 合成される。合成 されたALAはPBGからuro, copro，protoporphyrin をへてへム合成醉素により $\mathrm{Fe}^{*}$ をはめこまれてへ 


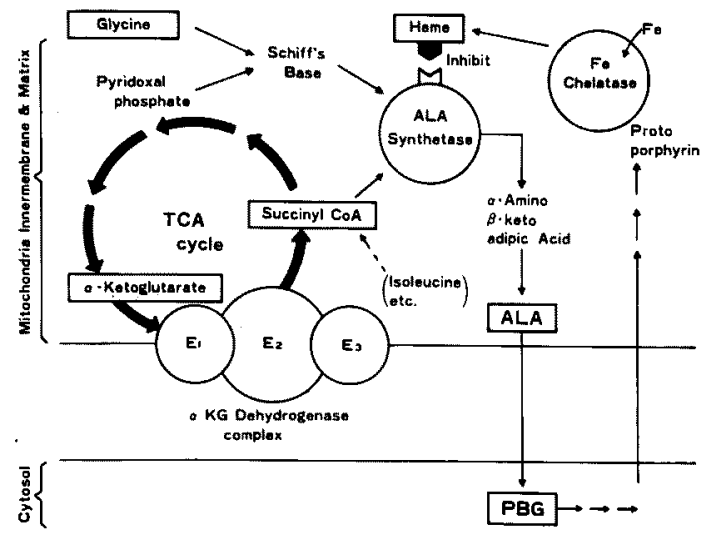

图3，肝に打けるALA合成経路

ムとなる．ALA合成を触媒するALA合成酵素がこ の一ム合成の律速段階であり" ${ }^{1}$ ，むし，ALAから へムの合成へのいずれかのステップの酵素に障害 があると，へムによるALA合成の抑制がはずれて ALA，PBGおよびporphyrin体の過剩産生により， 様々な臨床症状がひきおこされてくる.

今回の肝ALA合成活性の測定では，本例を始め とする肝性porphyria各型每に, $\mathrm{S}$ 活性, K活性の 上昇のしかたに，異なつたパターンが見られた。 従来から肝mitochondria分画には $\alpha \mathrm{KG}$ と succinyl CoAどららを用いてもALAを合成する活性のある ことが知られていたが，従来の合成活性について の検討は S 活性 (succinyl CoAを基質とした場合) についてのみが行なわれていた. succinyl CoAに 対する $\mathrm{km}$ 值は1 $10^{-3} \sim 10^{-4} \mathrm{M}$ 対 し, $\alpha \mathrm{KGでは10^{-4 } \sim ~}$ $10^{-5} \mathrm{M}$ 報告されており，しかるそれぞれの活性 をもつ分画が分離して抽出されている4).K活性, $\mathrm{S}$ 活性の関連については， $\alpha \mathrm{KG}$ 上り succinyl CoA をつくる $\alpha \mathrm{KG}$ 脱水素酵素とALA合成酵素が一種 の酵素複合体をつくり, succinyl CoAのうけ渡し を容易にしている可能性が考えられる， $\alpha \mathrm{KG}$ 脱 水素酵素とALA合成酵素はいずれる mitochondria の内膜, 基質分画に存在することが知られてい $ろ^{10) 11}$. S 活性が，このALA合成䣲素の活性のみ を示すのに対し，K活性はこの二つの酵素が複合 体を作つておうり，そのALA合成能を示している可
能性が大きいと思われるが，まだ不明の点も多 く，今後の検討を要すると思われる。

最近Bonkowskyらは，七トの肝生検組織を用い て, ALA合成が, succinyl CoA供給系の働きによ

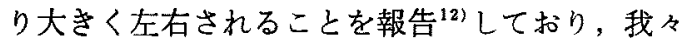
の結果とあわせて興味深い。

本例の場合，K活性は他の肝性porphyria と比較 してもはるかに高值を示した、VPにおいては， 尿中，便中に多量の porphyrin体が検出され，特に 便中のporphyrin体は無症状期にも高値を示すこと が知られている. porphyrin体の量が非常に多いた め皮店症状をひきおこすとる考えられており，今 回のK活性高値は，ALA合成の杂進をよく示して いるといえよう。

また，肝におけるALA合成醉素は，バルビター ル,5B-Hステロイドなどで誘導され ${ }^{5)}$, porphyriaの 症状を悪化させる。すたporphyriaの急性症状は， 女性の月経前の時期に多発する場合のあることが 知られている. 本例に拈いて子発症は，おそらく 第一子出産後の初回月経前に括こり,それがフェ ノバール投与により増悪させられたと思われる.

一方, 肝の組織所見では, 電顕的には, lysosome変性物様の特異な構造がみられ，これと類似 のmyeline figure様の構造がAIPにみられたとの Biempicaの報告や'13), PCTでも同じ構造を認め た我々の報告 ${ }^{18)}$ と共に, 肝性porphyriaに共通の特 徵的構造と思われる。た肝細胞内一の脂肪滴沈 着は，急性期の高脂血症と関連が考えられる。

AIPの患者ではuroporphyrinogen I 合成酵素活 性が, 肝蔵 ${ }^{14)}$, 赤血球 ${ }^{15)}$, 線維芽細胞 ${ }^{16)}$ で正常人 の約50\%低下しており，何らかのきつかけでALA 合成が上昇しても，入么合成量は増加せず，人ム による抑制がかからず，ALAが産生され急性增 悪をきたすとされている．PCTにおいても従来， ALA合成活性の上昇は示されていなかつたが2 今 回のK活性では上昇が確認されており, 生理的条 件ではALA合成が上昇していると思われる，遺伝 型PCTでは, coproporphripogen脱水素酵素の減少 ${ }^{17}$ が報告されそのためやはりへムによる抑制がとれ 
ALA合成の上昇することが考光られる，本症を始 め上するVPにおいてもALA合成活性の上昇から， へム合成系の他の酸素障害の確認が急がれるであ ろ5.

\section{文献}

1) 溥田郡平：ポルフィリン代謝異常総論。皮店蹦 床 $19: 11,1977$

2) Dowdle EB, et al: ALA synthetase activity in normal and porphyric human livers. $S$ Afr Med J 41 : 1093, 1967.

3) Kaufman L, et al: Biochemical defects in two types of human hepatic porphyrias. New Engl J Med 283: 954, 1970.

4) 浦田郡平, 近藤雅婎：ボルフィリン症におけ る酵素翼常。文部省特定研究「難病了班52年度 研究業績 534，1978。

5) Tschudy DP, et al: Acute intermittent porphyria. Ann Inter Med 83: 851, 1975.

6) Hellman ES, et al: Abnormal electrorite and water metabolism in acute intermittent porphyria. Amer J Med 32: 734, 1962.

7) Gibson JB and Goldberg A: The neurology of acute porphyria. J Pathol Bacteriol 71: $495,1956$.

8) Cavanagh JB and Mellic RS: On the nature of the peripheral nerve lesions associated with acute intermittent porphyria. Neurol Neurosurg Psychiatry 28: 320, 1965.

10) Zuyderhoudt FM, et al: Intramitochondrial localization of ALA synthetase. Biochem Biophys Acta 178: 408, 1969.

11) Schnaitman C, et al: Enzymatic properties of the inner and outer membrane of rat liver mitochondria. J Cell Biol 38: 158. 1968.

12) Bonkowsky HL, et al: Human hepatic ALA synthetase. Clin Sci Mol Med 52: 509, 1977.

13) Biempica L, et al: Hepatic porphyrias. Arch Pathol 98: 336, 1974.

14) Strand L, et al: Decreased red cell uroporphyrinogen-I synthetase activity in acute intermittent porphyria. J clin Invest $51: 2530$, 1972.

15) Strand L, et al: Enzymic abnormaritities in heme biosynthesis in acute intermittent porphyria. Proc Natl Acad Sci USA 67: 1315, 1970.

16) Meyer $U$, et al: Acute intermittent porphyria. Enzyme 16: 334, 1973.

17) Kushner JP, et al: An inherited enzyme defect in porphyria cutanea tarda. J clin Invest 58: 1089, 1976.

18）児玉竜彦，他：ポルフィリフ上肝障害，第13回 日本肝臓病学会東部会抄録, 肝臓. $20: 759$, 1978 . 